\title{
Growth and production components of West Indian cherry cultivated with saline waters and potassium fertilization
}

\author{
Geovani S. de Lima ${ }^{1}$, Francisco W. A. Pinheiro², Adaan S. Dias ${ }^{2}$, Hans R. Gheyi², \\ Lauriane A. dos A. Soares ${ }^{1} \&$ Saulo S. da Silva ${ }^{2}$
}

\begin{abstract}
${ }^{1}$ Universidade Federal de Campina Grande/Centro de Ciências e Tecnologia Agroalimentar/Programa de Pós-Graduação em Horticultura Tropical. Pombal, PB, Brasil.E-mail: geovani.soares@pq.cnpq.br (Corresponding author) - ORCID: 0000-0001-9960-1858; lauriane.soares@pq.cnpq.br-ORCID: 0000-0002-7689-9628 ${ }_{2}^{2}$ Universidade Federal de Campina Grande/Centro de Tecnologia e Recursos Naturais/Programa de Pós-Graduação em Engenharia Agrícola. Campina Grande, PB, Brasil. E-mail: wesley.ce@hotmail.com - ORCID: 0000-0002-5589-6882; sudario_dias@hotmail.com - ORCID: 0000-0002-2247-1511; saulosoares90@gmail.com ORCID: 0000-0002-1049-6519

${ }^{3}$ Universidade Federal do Recôncavo da Bahia/Núcleo de Engenharia de Água e Solo. Cruz das Almas, BA, Brasil. E-mail: hans@pq.cnpq.br - ORCID: 0000-0002-1066-0315
\end{abstract}

\begin{abstract}
Due to water limitations in terms of both quantity and quality in the semi-arid region of northeastern Brazil, the use of waters with high concentrations of salts become necessary in irrigated agriculture. Thus, this study aimed to evaluate the growth and production of grafted West Indian cherry under saline water irrigation and potassium fertilization. The experiment was carried out in drainage lysimeters under protected environment conditions, using a Regolithic Neosol with sandy loam texture. Treatments resulted from the combination of two levels of electrical conductivity - ECw $\left(0.8\right.$ and $\left.3.8 \mathrm{dS} \mathrm{m}^{-1}\right)$ of irrigation water and four doses of potassium (50,75, 100 and 125\% of the recommendation of Musser), arranged in a randomized block design, with three replicates. Irrigation water salinity of $3.8 \mathrm{dS} \mathrm{m} \mathrm{m}^{-1}$ markedly inhibited the growth in stem diameter and mean fruit weight of West Indian cherry. Potassium fertilization mitigated the deleterious effects of salt stress on the relative growth in stem diameter of the rootstock, total number of fruits and total fresh mass of fruits of West Indian cherry, with highest values in plants irrigated with water of lowest level of salinity associated with the highest dose of $\mathrm{K}_{2} \mathrm{O}$.
\end{abstract}

Key words: Malpighia emarginata, salt stress, osmoregulation

\section{Crescimento e componentes de produção da aceroleira cultivada com águas salinas e adubação potássica}

RESUMO: Devido às limitações hídricas tanto em termos quantitativos como qualitativos na região semiárida do Nordeste brasileiro, o uso de águas com elevadas concentrações de sais torna-se necessário para agricultura irrigada. Deste modo, objetivou-se com este trabalho, avaliar o crescimento e a produção da aceroleira enxertada sob irrigação com água salina e adubação potássica. O experimento foi conduzido em lisímetros de drenagem sob condições de ambiente protegido, utilizando-se um Neossolo Regolítico de textura franco-arenosa. Os tratamentos resultaram da combinação entre dois níveis de condutividade elétrica da água de irrigação - $\mathrm{CEa}\left(0,8\right.$ e 3,8 dS m $\left.\mathrm{m}^{-1}\right)$ e quatro doses de potássio $(50,75,100$ e $125 \%$ da recomendação de Musser), dispostos no delineamento de blocos casualizados, com três repetições. A salinidade da água de irrigação de 3,8 $\mathrm{dS} \mathrm{m}^{-1}$ inibiu acentuadamente o crescimento em diâmetro caulinar e o peso médio de frutos da aceroleira. A adubação potássica mitigou os efeitos deletérios do estresse salino sobre o crescimento relativo do diâmetro caulinar do porta-enxerto, número total de frutos e a massa fresca total de frutos de aceroleira, com os maiores valores nas plantas irrigadas com água de menor salinidade associada à maior dose de $\mathrm{K}_{2} \mathrm{O}$.

Palavras-chave: Malpighia emarginata, estresse salino, osmorregulação 


\section{INTRODUCTION}

West Indian cherry (Malpighia emarginata) is a fruit crop widely grown in the semi-arid region of Northeast Brazil and stands out for its high nutritional value, especially as a source of ascorbic acid, vitamin A, iron, calcium and vitamins B-complex: thiamine, riboflavin and niacin (Esashika et al., 2013). It is consumed both fresh and industrialized, emerging as a way to boost the economy and as an alternative for the development of the region (Almeida et al., 2014).

In the semi-arid region of Northeast Brazil, salt stress stands out among the abiotic stresses that most hamper the growth and yield of agricultural species (Islã \& Aragués, 2010; Sales et al., 2015), due to the reduction in the osmotic potential of the soil solution and to the possible occurrence of nutritional imbalance and metabolic disorders, both caused by high concentration of toxic ions in the protoplasm, especially $\mathrm{Na}^{+}$ and $\mathrm{Cl}^{-}$(Khan \& Panda, 2008; Flowers et al., 2014).

Osmotic and ionic effects on crops can cause alterations in the physiological and biochemical functions of plants, which lead to disorders in water relations and, consequently, to alterations in the absorption and use of nutrients (Amorim et al., 2010; Ouhaddach et al., 2018). One of the inconveniences is that the response of plants to salinity are complex and depend on other factors such as species, cultivar, types of salts, plant age, stress intensity and duration, crop and irrigation management, edaphoclimatic conditions and fertilization (Munns \& Tester, 2008).

Thus, knowledge on the degree of tolerance of crops to salinity may allow the use of waters with a high concentration of salts, a common situation found in the semi-arid region of Northeast Brazil (Nobre et al., 2010; Souza et al., 2017). For this purpose, it is necessary to conduct studies in order to identify salinity-tolerance indices of crops, including West Indian cherry, aiming to establish the degree of restriction of certain types of water for irrigation (Lima et al., 2014), because there are few studies in the literature with this fruit crop under salt stress conditions in the post-grafting stage (Sá et al., 2017, 2018).

The importance of potassium fertilization in West Indian cherry cultivation is due to its physiological role in the activation of various enzymatic systems and phosphorylation reactions, which are fundamental for the metabolic processes, especially the production of proteins and sugars. It also promotes increase in the translocation of carbohydrates in plants, improves water use efficiency, enhances nitrogen fertilization, and can favor the quality of the product to be marketed, among other functions (Marschner, 2012). Potassium accumulation in the plant causes an osmotic gradient that facilitates the movement of water between its cells, controlling stomatal opening and closure, playing a fundamental role in cell turgor and leaf transpiration (Melo et al., 2014).

This study aimed to evaluate the absolute and relative growth rates in stem diameter of the rootstock and scion and the production components of grafted West Indian cherry plant under saline water irrigation and potassium fertilization.

\section{Material ANd Methods}

The study was carried out in pots adapted as drainage lysimeters under greenhouse conditions, at the Center of Technology and Natural Resources of the Federal University of Campina Grande (CTRN/UFCG), in the municipality of Campina Grande, $\mathrm{PB}$, Brazil, located at geographic coordinates $7^{\circ} 15^{\prime} 18^{\prime \prime} \mathrm{S}, 35^{\circ} 52^{\prime} 28^{\prime \prime} \mathrm{W}$ and altitude of $550 \mathrm{~m}$.

The experiment was conducted in randomized block design, with three replicates and one plant per plot, using a $2 \times 4$ factorial arrangement, composed of two levels of electrical conductivity - ECw ( 0.8 and $\left.3.8 \mathrm{dS} \mathrm{m}^{-1}\right)$ of irrigation water and four doses of potassium [50, 75, 100 and 125\% of the recommendation of Musser (1995)]. The dose of $100 \%$ corresponded to $19.8 \mathrm{~g}$ of $\mathrm{K}_{2} \mathrm{O}$ plant $^{-1}$ year $^{-1}$.

Irrigation waters with the respective levels of electrical conductivity were prepared by dissolving the salts $\mathrm{NaCl}$, $\mathrm{CaCl}_{2} \cdot 2 \mathrm{H}_{2} \mathrm{O}$ and $\mathrm{MgCl}_{2} \cdot 6 \mathrm{H}_{2} \mathrm{O}$, at equivalent proportion of $7: 2: 1$, respectively, in water from the public supply system $(\mathrm{ECw}=$ $1.40 \mathrm{dS} \mathrm{m}^{-1}$ ) of the municipality of Campina Grande, PB, based on the relationship between ECw and the concentration of salts

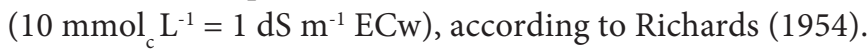
Water with ECw of $0.8 \mathrm{dS} \mathrm{m}^{-1}$ was obtained by mixing publicsupply water with rainwater $\left(0.02 \mathrm{dS} \mathrm{m}^{-1}\right)$.

At the bottom of each lysimeter a drain was installed to drain excess water into a plastic container, in order to determine water consumption by plants. The tip of the drain inside the pot was involved in a nonwoven geotextile (Bidim OP 30) to avoid clogging by soil material.

The lysimeters were filled with a $1 \mathrm{~kg}$ layer of crushed stone $\mathrm{N}^{\circ} 0$, followed by $250 \mathrm{~kg}$ of soil from the $0-20 \mathrm{~cm}$ layer of a Regolithic Neosol with sandy loam texture, properly pounded to break up clods, from the rural area of the municipality of Esperança-PB, whose chemical and physical characteristics are shown in Table 1 and were obtained according to the methodologies proposed by Donagema et al. (2011).

The rootstock was obtained from seedlings of landraces of West Indian cherry provided by Embrapa Agroindústria

Table 1. Chemical and physical characteristics of the soil used in the experiment

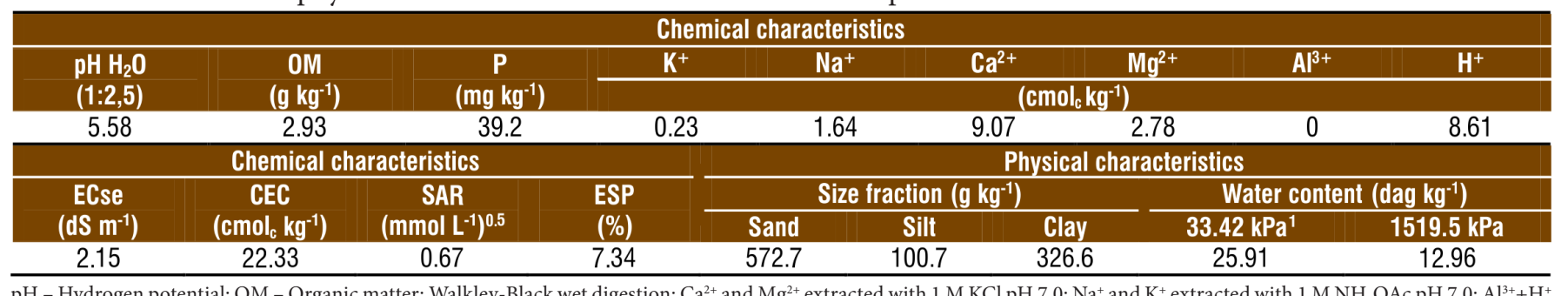

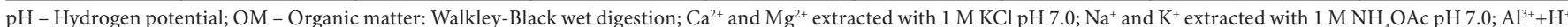
extracted with $0.5 \mathrm{M} \mathrm{CaOAc} \mathrm{pH} 7.0$; ECse - Electrical conductivity of the saturation extract; CEC - Cation exchange capacity; SAR - Sodium adsorption ratio of the saturation extract; ESP - Exchangeable sodium percentage 
Tropical, located in Pacajus-CE. The scion cultivar used was the 'BRS 366 Jaburu', which stands out for its high yield (57 $\mathrm{t} \mathrm{ha}^{-1}$ ) (EMBRAPA, 2012). Seedlings were transplanted when they were 240 days old. During the acclimation period in the greenhouse environment, West Indian cherry plants were irrigated with low-salinity water $\left(0.8 \mathrm{dS} \mathrm{m}^{-1}\right)$.

Prior to transplanting the seedlings, soil moisture content was increased up to field capacity using waters of respective treatment. After transplanting, irrigation was conducted daily, applying a water volume sufficient to maintain the soil close to field capacity and the volume to be applied was determined using Eq. 1:

$$
\mathrm{VI}=\frac{(\mathrm{Va}-\mathrm{Vd})}{1-\mathrm{LF}}
$$

where:

VI - water volume to be used in the irrigation event, $\mathrm{mL}$;

$\mathrm{Va}$ - volume applied in the previous irrigation event, $\mathrm{mL}$;

$\mathrm{Vd}$ - volume drained, $\mathrm{mL}$; and,

LF - leaching fraction, 0.10 .

Fertilization with phosphorus and nitrogen was carried out as recommended by Musser (1995), applying 250 and 53 g plant $^{-1}$, respectively, of single superphosphate and urea. Phosphate fertilization was applied in the soil 15 days before transplanting, whereas nitrogen and potassium fertilizations were split into 12 equal portions, applied monthly. To meet the requirements of micronutrients, a solution of Ubyfol containing $1.5 \mathrm{~g} \mathrm{~L}^{-1}[(\mathrm{~N}$ (15\%); $\mathrm{P}_{2} \mathrm{O}_{5}$ (15\%); $\mathrm{K}_{2} \mathrm{O}$ (15\%); $\mathrm{Ca}(1 \%) ; \mathrm{Mg}(1.4 \%) ; \mathrm{S}(2.7 \%)$; $\mathrm{Zn}(0.5 \%) ; \mathrm{B}(0.05 \%) ; \mathrm{Fe}(0.5 \%) ; \mathrm{Mn}(0.05 \%) ; \mathrm{Cu}(0.5 \%) ; \mathrm{Mo}$ $(0.02 \%)]$ was sprayed on the leaves every week.

The absolute and relative growth rates in stem diameter of rootstock $\left(\mathrm{AGR}_{\mathrm{DR}}\right.$ and $\left.\mathrm{RGR}_{\mathrm{DR}}\right)$ and scion $\left(\mathrm{AGR}_{\mathrm{DS}}\right.$ and $R_{G R}$ ) were evaluated in the period from 30 to 515 days after transplanting (DAT). Harvest began at $180 \mathrm{DAT}$ and continued until 515 DAT, and the following variables were determined: total number of fruits plant ${ }^{-1}$ (TNF), total fresh mass of fruits (TMF, g plant $^{-1}$ ) and mean fruit mass (MFM, g plant ${ }^{-1}$ ).

The AGR and RGR in stem diameter of rootstock and scion of West Indian cherry plants were determined according to Benincasa (2003), using Eqs. 2 and 3.

$$
\mathrm{AGR}=\frac{(\mathrm{SD} 2-\mathrm{SD} 1)}{(\mathrm{t} 2-\mathrm{t} 1)}
$$

where:

AGR - absolute growth rate in stem diameter of rootstock and scion $\left(\mathrm{cm} \mathrm{d}^{-1}\right)$,

$\mathrm{SD}_{1}$ - stem diameter and scion $(\mathrm{mm})$ at time $\mathrm{t}_{1}$ (day); and, $\mathrm{SD}_{2}$ - stem diameter and scion $(\mathrm{mm})$ at time $\mathrm{t}_{2}$ (day).

$$
\mathrm{RGR}=\frac{(\operatorname{InSD} 2-\operatorname{InSD} 1)}{(\mathrm{t} 2-\mathrm{t} 1)}
$$

where:

RGR - relative growth rate in stem diameter $\left(\mathrm{mm} \mathrm{mm}^{-1} \mathrm{~d}^{-1}\right)$; and,

ln - natural logarithm.

The data were subjected to analysis of variance by $\mathrm{F}$ test and, when significant, means comparison test (Tukey at 0.05 probability level) was conducted for water salinity levels (SL) and the regression analysis was carried out for potassium doses (KD). When the interaction between the factors was significant, potassium doses were further analyzed for each salinity level, using the statistical program Sisvar (Ferreira, 2011).

\section{Results ANd Discussion}

There was significant effect $(\mathrm{p}<0.05)$ of salinity levels on the absolute and relative growth rates in stem diameter of rootstock $\left(\mathrm{AGR}_{\mathrm{DR}} / \mathrm{RGR}_{\mathrm{DR}}\right)$ and scion $\left(\mathrm{AGR}_{\mathrm{DS}} / \mathrm{RGR}_{\mathrm{DS}}\right)$ of West Indian cherry plants (Table 2). Potassium doses alone did not significantly influence ( $\mathrm{p}>0.05)$ any of the variables analyzed, but the interaction between factors (KD x SL) significantly affected $(\mathrm{p}<0.05)$ the $\mathrm{RGR}_{\mathrm{DR}}$ in the period from 30 to 515 days after transplanting. Sá et al. (2017), in a study with West Indian cherry cv. 'BRS 366 Jaburu' under water salinity (ECw from 0.6 to $3.8 \mathrm{dS} \mathrm{m}^{-1}$ ) and fertilization with nitrogen and phosphorus, observed that the supply of $\mathrm{N}$ and $\mathrm{P}$ did not significantly influence the absolute and relative growth rates in stem diameter of scion and rootstock.

Based on the comparison of means (Figure 1A), it can be observed that the $A_{G R}$ of plants irrigated using water with the highest level of salinity $\left(3.8 \mathrm{dS} \mathrm{m}^{-1}\right)$ decreased by $0.0064 \mathrm{~mm} \mathrm{~d}^{-1}(11.77 \%)$, compared to those irrigated with $0.8 \mathrm{dS} \mathrm{m}^{-1}$ water. The reduction in the absolute growth rate in rootstock diameter was possibly due to the redirection of energy used to store sugars, organic acids and ions in the vacuole, for the osmotic adjustment, promoting metabolic changes, particularly

Table 2. Summary of analysis of variance for absolute $\left(\mathrm{AGR}_{\mathrm{DR}}\right)$ and relative growth rates $\left(\mathrm{RGR}_{\mathrm{DR}}\right)$ of stem diameter of rootstock

\begin{tabular}{|c|c|c|c|c|c|}
\hline \multirow{2}{*}{ Source of variation } & \multirow{2}{*}{ DF } & \multicolumn{4}{|c|}{ Mean squares } \\
\hline & & $\overline{\mathrm{AGR}_{\mathrm{DR}}}$ & $\overline{\mathbf{R G R}_{\mathrm{DR}}}$ & $\mathrm{AGR}_{\mathrm{DS}}$ & $\mathbf{R G R}_{\mathrm{DS}}$ \\
\hline Saline levels (SL) & 1 & $0.00024^{*}$ & $0.000002^{\star}$ & $0.00024^{*}$ & $0.0000009^{*}$ \\
\hline K doses (KD) & 3 & $0.00001^{\text {ns }}$ & $0.0000006^{n s}$ & $0.000002^{\mathrm{ns}}$ & $0.00000007^{\mathrm{ns}}$ \\
\hline Linear regression & 1 & $0.00004^{\mathrm{ns}}$ & $0.000001^{*}$ & $0.0000001^{\text {ns }}$ & $0.0000001^{\mathrm{ns}}$ \\
\hline Quadratic regression & 1 & $0.000005^{\text {ns }}$ & $0.0000001^{\mathrm{ns}}$ & $0.000005^{\mathrm{ns}}$ & $0.000002^{\text {ns }}$ \\
\hline Interaction (SL x KD) & 3 & $0.00009^{n s}$ & $0.000001^{*}$ & $0.00003^{\mathrm{ns}}$ & $0.00000007^{\mathrm{ns}}$ \\
\hline Blocks & 2 & $0.00004^{\mathrm{ns}}$ & $0.00000006^{\text {ns }}$ & $0.000002^{\text {ns }}$ & $0.00000008^{\mathrm{ns}}$ \\
\hline CV (\%) & & 9.86 & 10.34 & 14.28 & 8.87 \\
\hline
\end{tabular}
and of scion of West Indian cherry plants irrigated using waters of different salinity levels and potassium doses, in the period from 30 to 515 days after transplanting

ns, ${ }^{*}$ Respectively, not significant, significant at $\mathrm{p}<0.05$ 

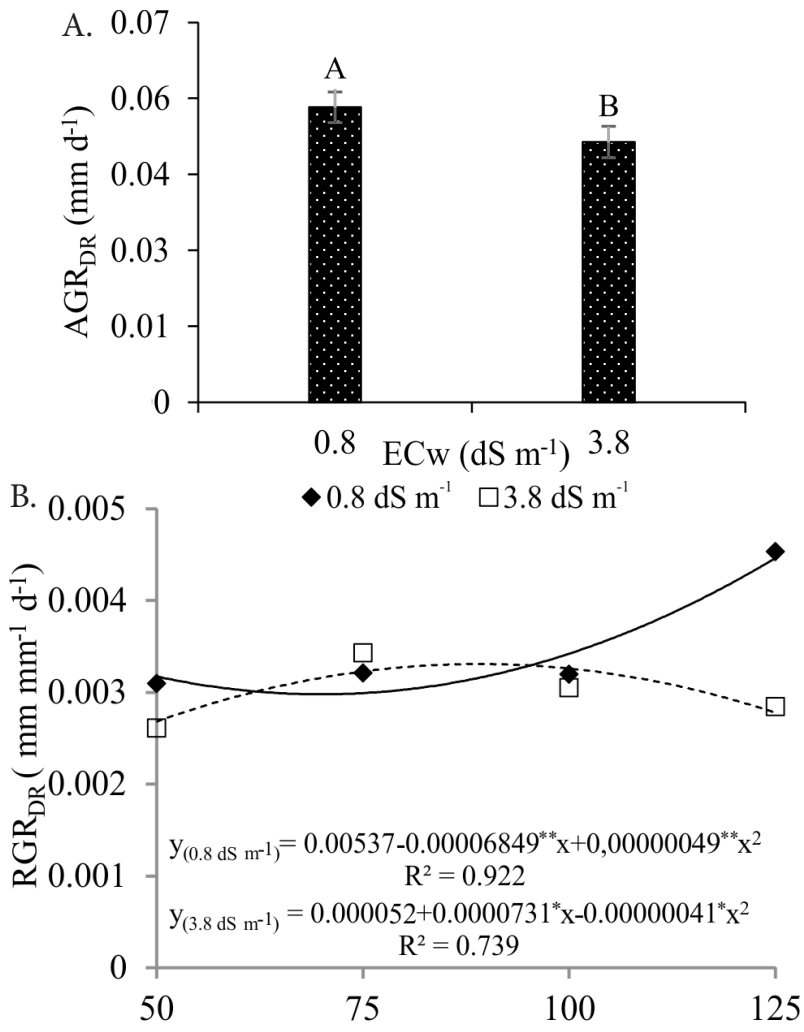

Potassium doses ( $\%$ of recommendation)

Bars represent the standard error of the mean $(n=3)$. Means with different letters indicate that the treatments differ by Tukey test, $\mathrm{p}<0.05$

Figure 1. Absolute growth rate - $A_{G R}(A)$ in diameter of grafted West Indian cherry plants irrigated using saline waters - ECw and relative growth rate - $\mathrm{RGR}_{\mathrm{DR}}(\mathrm{B})$ in diameter of rootstock as a function of the interaction between irrigation water electrical conductivity (ECw) and potassium doses (B) in the period from 30 to 515 days after transplanting

through the reduction in the absorption of water and nutrients (Graciano et al., 2011). Mesquita et al. (2014), in studies with papaya plants cultivated in protected environment under saline conditions (ECw from 0.5 to $4.0 \mathrm{dS} \mathrm{m}^{-1}$ ), observed reduction in the absolute growth rate in stem diameter as irrigation water salinity increased.

The relative growth rate in diameter of West Indian cherry rootstock was significantly affected by the interaction between factors (KD x SL) and, according to the regression equations (Figure 1B), the data of plants irrigated with ECw of 0.8 and $3.8 \mathrm{dS} \mathrm{m}^{-1}$ fitted to the quadratic model, whose maximum estimated values of $\mathrm{RGR}_{\mathrm{DR}}(0.004469$ and 0.003300 $\mathrm{mm} \mathrm{mm}^{-1} \mathrm{~d}^{-1}$ ) were reached, respectively, at $\mathrm{K}_{2} \mathrm{O}$ doses of 125 and $95 \%$ of the recommendation of Musser. It can be noted that West Indian cherry plants irrigated with the lowest ECw level had an increment of $0.001295 \mathrm{~mm} \mathrm{~mm}^{-1} \mathrm{~d}^{-1}$ in $\mathrm{RGR}_{\mathrm{DR}}$, comparing $\mathrm{K}_{2} \mathrm{O}$ doses of 50 and $125 \%$ of the recommendation. In addition, it can also be observed that the $\mathrm{K}_{2} \mathrm{O}$ dose of $125 \%$ led to increase of $0.00010 \mathrm{~mm} \mathrm{~mm}^{-1} \mathrm{~d}^{-1}$ compared to plants which received only $50 \%$ of the recommendation of potassium fertilization. The increment in the $\mathrm{RGR}_{\mathrm{DR}}$ of West Indian cherry plants reflects the physiological role of potassium in the osmoregulation, being directly involved in the regulation of cell osmotic potential, favoring homeostasis and cell expansion (Melo et al., 2014).
Irrigation with saline water increased the concentration of salts in the soil and caused reductions in the absolute and relative growth rates of West Indian cherry, in the period from 30 to 515 days after transplanting. It can be observed (Figure $2 \mathrm{~A})$ that irrigation water salinity of $3.8 \mathrm{dS} \mathrm{m}^{-1}$ negatively affected the absolute growth rate in scion diameter $\left(\mathrm{AGR}_{\mathrm{DS}}\right.$ ) of grafted West Indian cherry plants, with reduction of $13.87 \%$ $\left(0.0063 \mathrm{~mm} \mathrm{~d}^{-1}\right)$ compared to those irrigated with $0.8 \mathrm{dS} \mathrm{m}^{-1}$ water (Figure 2A). The reduction in growth rate is also due to the deleterious effect of excess salts on plant metabolism, because the excess of soluble salts in the root zone causes a reduction of turgor, with consequent decrease in cell expansion (Khalid \& Silva, 2010). Sá et al. (2018), evaluating the effects of water salinity (ECw: $0.6 ; 1.4 ; 2.2 ; 3.0$ and $3.8 \mathrm{dS} \mathrm{m}^{-1}$ ) on the growth of West Indian cherry plants, also observed that increase in $\mathrm{ECw}$ led to reduction in the absolute and relative growth rates of stem diameter, in the period from 1 to 150 days after transplanting.

The increase in ECw led to reduction in the relative growth rate in scion diameter $\left(\mathrm{RGR}_{\mathrm{DS}}\right)$ in the period from 30 to 515 days after transplanting (Figure $2 \mathrm{~B}$ ). According to the data of $\mathrm{RGR}_{\mathrm{DS}}$, it is possible to observe that the highest value was found when plants were irrigated using water with lowest ECw $\left(0.8 \mathrm{dS} \mathrm{m}^{-1}\right)$, a maximum of $0.0033 \mathrm{~mm} \mathrm{~mm}^{-1} \mathrm{~d}^{-1}$. This trend was also observed for the relative growth rate in stem diameter of rootstock, which corroborates the reduction in the growth of plants when subjected to salt stress (Claeys et al., 2014). Similar results were obtained by Mesquita et al. (2012), who evaluated the effects of irrigation water salinity on the absolute and relative growth of yellow passion fruit seedlings in soil with bovine biofertilizer and observed that the increase
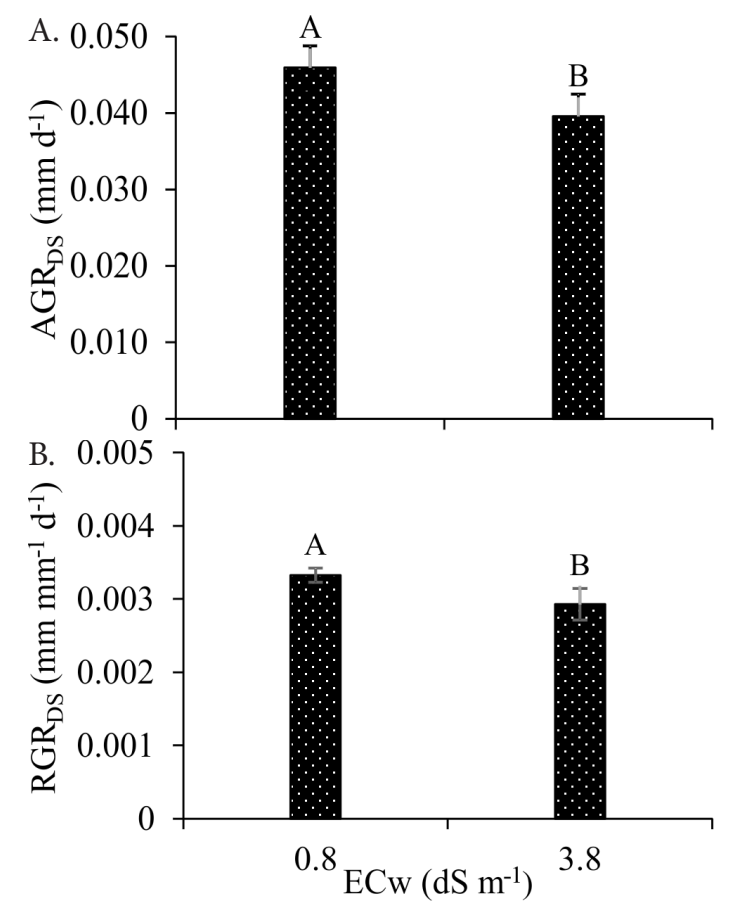

Bars represent the standard error of the mean $(n=3)$. Means with different letters indicate that the treatments differ by Tukey test, $\mathrm{p}<0.05$

Figure 2. Absolute - $\mathrm{AGR}_{\mathrm{DS}}(\mathrm{A})$ and relative growth rates in stem diameter of the scion $-\mathrm{RGR}_{\mathrm{DS}}(\mathrm{B})$ of grafted West Indian cherry plants irrigated with saline water - ECw, in the period from 30 to 515 days after transplanting 
in water salinity reduced the absolute and relative growth rates in stem diameter.

There was significant effect of water salinity levels on the total number of fruits (TNF), total fresh mass of fruits (TFM) and mean fruit mass (MFM) (Table 3). Potassium doses and the interaction between factors (KD x SL) significantly influenced TNF and TFM.

According to the behavior of this variable, when plants were irrigated using water with lowest salinity level $\left(0.8 \mathrm{dS} \mathrm{m}^{-1}\right)$, as potassium doses increased there was an increment in TNF, and the highest estimated value of 225.20 fruits plant ${ }^{-1}$ was obtained in plants under $125 \%$ of the $\mathrm{K}_{2} \mathrm{O}$ recommendation. However, in plants subjected to irrigation with water of highest $\mathrm{ECw}$ $\left(3.8 \mathrm{dS} \mathrm{m}^{-1}\right)$, the TNF increased only up to the estimated dose of $91 \%$ of $\mathrm{K}_{2} \mathrm{O}$ recommendation (158.21 fruits plant ${ }^{-1}$ ) and, from this dose on, there was a sharp reduction in this variable. Despite the reduction in TNF due to irrigation with saline water of $3.8 \mathrm{dS} \mathrm{m}^{-1}$, it can be observed (Figure $3 \mathrm{~A}$ ) that for ECw of $0.8 \mathrm{dS} \mathrm{m} \mathrm{m}^{-1}$, plants subjected to the highest potassium dose (125\% of the recommendation of Musser) showed a $37.05 \%$ increase compared to those under the $\mathrm{K}_{2} \mathrm{O}$ dose of $50 \%$. Thus, the results obtained for TNF highlight the importance of potassium in the participation in several biochemical and physiological processes, such as photosynthesis, and transport and storage of assimilates, responsible for increasing crop yield (Oliveira et al., 2013).

As observed for $\mathrm{RGR}_{\mathrm{DR}}$ (Figure $1 \mathrm{~B}$ ), the total number of fruits (Figure $3 \mathrm{~A}$ ) responded significantly to the effects of the interaction between factors (KD x SL). The data of TFM for West Indian cherry plants subjected to irrigation with ECw of $0.8 \mathrm{dS} \mathrm{m}^{-1}$ fitted to a linear positive model, with $203.47 \%$ increment for every $25 \%$ increase in $\mathrm{K}_{2} \mathrm{O}$ recommendation, i.e., the TFM of plants fertilized with $125 \%$ of $\mathrm{K}_{2} \mathrm{O}$ increased by $666.29 \mathrm{~g} \mathrm{plant}^{-1}$, compared to those under $50 \%$ of $\mathrm{K}_{2} \mathrm{O}$ recommendation. On the other hand, for the TFM of plants under ECw of $3.8 \mathrm{dS} \mathrm{m}^{-1}$ (Figure 3B), the maximum estimated value of 278.76 g plant $^{-1}$ occurred when plants received $94 \%$ of the potassium fertilization recommended by Musser (1995).

By comparing the TFM of plant under ECw of $3.8 \mathrm{dS} \mathrm{m}^{-1}$, it can be noted that there were relative increments of $79.38 \mathrm{~g} \mathrm{plant}^{-1}$ $(38.56 \%)$ in those which received the highest dose of $\mathrm{K}_{2} \mathrm{O}(125 \%$ of the recommendation), relative to those under $50 \%$ of $\mathrm{K}_{2} \mathrm{O}$. In addition, according to the regression equations (Figure $3 \mathrm{~B}$ ),

Table 3. Summary of analysis of variance for total number of fruits (TNF), total fresh mass of fruits (TFM) and mean fruit mass (MFM) of grafted West Indian cherry irrigated with waters of different salinity levels and potassium doses, at 515 days after transplanting

\begin{tabular}{lcccc|}
\hline \multirow{2}{*}{ Source of variation } & \multirow{2}{*}{ DF } & \multicolumn{3}{c|}{ Mean squares } \\
\cline { 3 - 5 } Saline levels (SL) & 1 & TNF & TFM & MFM \\
K doses (KD) & 3 & $4765.37^{\star}$ & $2710014.74^{\star *}$ & $91.10^{\star *}$ \\
Linear regression & 1 & $14105.00^{* *}$ & $273465.38^{*}$ & $0.47^{\text {ns }}$ \\
Quadratic regression & 1 & $77.04^{\text {ns }}$ & $130395.96^{*}$ & $0.07^{\text {ns }}$ \\
\hline Interaction (SL x KD) & 3 & $12393.93^{* *}$ & $168252.55^{*}$ & $0.37^{\text {ns }}$ \\
Blocks & 2 & $144.29^{\text {ns }}$ & $27073.29^{\text {ns }}$ & $0.54^{\text {ns }}$ \\
Residual & 14 & 588.29 & 27439.92 & 0.17 \\
CV (\%) & & 18.88 & 30.09 & 10.28 \\
\hline
\end{tabular}

ns, $* *,{ }^{*}$ Respectively, not significant, significant at $\mathrm{p}<0.01$ and $\mathrm{p}<0.05$
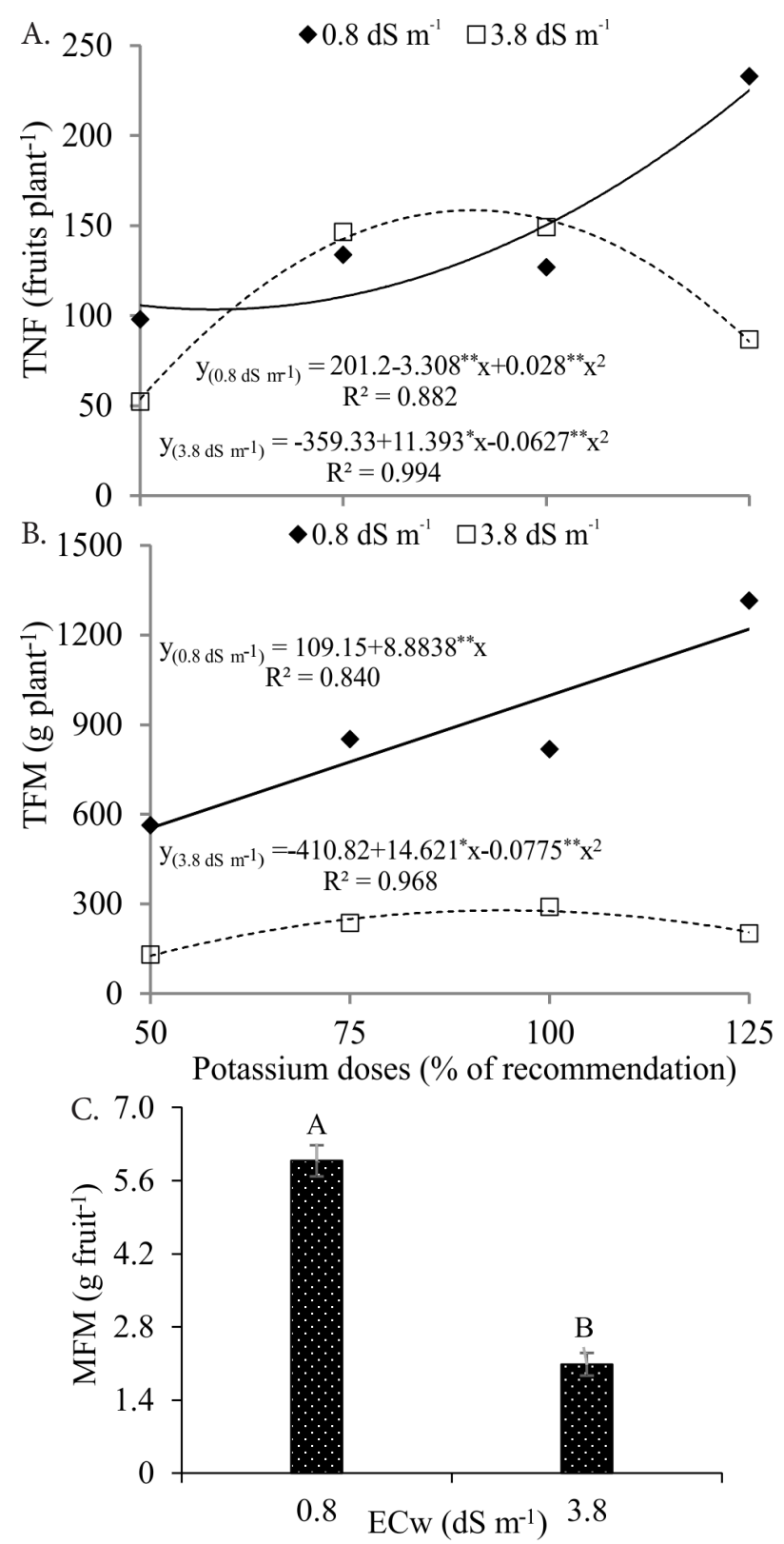

Bars represent the standard error of the mean $(n=3)$. Means with different letters indicate that the treatments differ by Tukey test, $\mathrm{p}<0.05$

Figure 3. Total number of fruits - TNF (A) and total fresh mass of fruits - TFM (B), as a function of the interaction between irrigation water salinity - ECW and potassium doses, and mean fruit mass - MFM (C) of West Indian cherry plants irrigated with saline waters, at 515 days after transplanting

although there was a reduction in TFM due to the irrigation with saline water, always when the $\mathrm{K}_{2} \mathrm{O}$ dose increased from 50 to $125 \%$ there was an increment in TFM. It can be inferred that the physiological function performed by potassium in the photosynthetic process, through the maintenance of turgor in guard cells, controlling stomatal opening and closure and in the regulation of cell osmotic potential, causes this macronutrient to decisively influence the growth of plants and, therefore, their yield (Langer et al., 2004).

In relation to the mean fruit mass of West Indian cherry fruits (Figure 3C), the highest value (5.98 $\mathrm{g} \mathrm{fruit}^{-1}$ ) occurred in plants irrigated using water with the lowest salinity level $\left(0.8 \mathrm{dS} \mathrm{m}^{-1}\right)$, being statistically higher than the value $\left(2.08 \mathrm{~g} \mathrm{fruit}^{-1}\right)$ observed in plants under irrigation with $\mathrm{ECw}$ of $3.8 \mathrm{dS} \mathrm{m}^{-1}$. 
From the results obtained for MFM (Figure 3C), it is possible to note that the value obtained in plants subjected to the lowest ECw level is within the range recommended for the West Indian cherry cultivar 'BRS 366 Jaburu', since Embrapa Tropical Agroindustry cites that fruits of this cultivar weigh on average 4 to $5 \mathrm{~g}$ when ripe.

There was a reduction in the MFM of $3.90 \mathrm{~g}(65.15 \%)$ between plants irrigated using water with ECw of $3.8 \mathrm{dS} \mathrm{m}^{-1}$ and those subjected to $0.8 \mathrm{dS} \mathrm{m}^{-1}$ (Figure $3 \mathrm{C}$ ). Reduction in MFM due to water salinity is consistent with the absolute and relative growth rates for the diameter of rootstock and scion of West Indian cherry plants (Figures 1 and 2) and expresses the response of the decrease in the osmotic potential and/or excessive accumulation of ions in the protoplasm (Flowers et al., 2014). In this context, there may have been higher metabolic costs for osmoregulation, which could be achieved by means of accumulation and compartmentation of inorganic solutes in the vacuole and organic solutes in the cytoplasm (Garcia et al., 2010).

\section{Conclusions}

1. Increase in irrigation water salinity from 0.8 to $3.8 \mathrm{dS} \mathrm{m}^{-1}$ inhibits the absolute and relative growths in stem diameter and mean mass of fruits of West Indian cherry, in the postgrafting stage.

2. Potassium fertilization mitigates the deleterious effects of salt stress on the relative growth rate of rootstock diameter, total number of fruits and total fresh mass of fruits of West Indian cherry, with highest values in plants irrigated using water of lowest salinity associated with highest dose of $\mathrm{K}_{2} \mathrm{O}$.

\section{ACKNOWLEDGMENTS}

To the National Program of Post-Doctorate (PNPD/ CAPES/UFCG), for granting the scholarship to the first author and to the National Institute of Science and Technology in Salinity - INCTSal, for funding the project.

\section{Literature Cited}

Almeida, J. P. N. de; Dantas, L. L. de G. R.; Arrais, I. G.; Tosta, M. da S.; Mendonça, V. Fungo micorrízico arbuscular e extrato de algas no crescimento inicial de porta-enxerto de aceroleira. Revista de Ciências Agrárias, v.57, p.22-28, 2014. https://doi.org/10.4322/ rca.2013.061

Amorim, A. V.; Gomes Filho, E.; Bezerra, M. A.; Prisco, J. T.; Lacerda, C. F. de. Respostas fisiológicas de plantas adultas de cajueiro anão precoce à salinidade. Revista Ciência Agronômica, v.41, p.113-121, 2010.

Benincasa, M. M. P. Análise de crescimento de plantas, noções básicas. 2.ed. Jaboticabal: FUNEP, 2003. 41p.

Claeys, H.; Landeghem, S. van; Dubois, M.; Maleux, K.; Inzé, D. What is stress? Dose-response effects in commonly used in vitro stress assays. Plant Physiology, v.165, p.519-527, 2014. https:// doi.org/10.1104/pp.113.234641

Donagema, G. K.; Campos, D. V. B. de; Calderano, S. B.; Teixeira, W. G.; Viana, J. H. M. (orgs.). Manual de métodos de análise de solo. 2.ed. Rio de Janeiro: Embrapa Solos, 2011. 230p.
EMBRAPA - Empresa Brasileira de Pesquisa Agropecuária. Cultivar acerola BRS 366-Jaburu. Fortaleza: Embrapa Agroindústria Tropical, 2012. 2p.

Esashika, T.; Oliveira, L. A. de; Moreira, F. W. Resposta da aceroleira a adubação orgânica, química e foliar num Latossolo da Amazônia Central. Revista de Ciências Agrárias, v.36, p.399-410, 2013.

Ferreira, D. F. Sisvar: A computer statistical analysis system. Ciência e Agrotecnologia, v.35, p.1039-1042, 2011. https://doi.org/10.1590/ S1413-70542011000600001

Flowers, T. J.; Munns, R.; Colmer, T. D. Sodium chloride toxicity and the cellular basis of salt tolerance in halophytes. Annals of Botany, v.115, p.419-431, 2014. https://doi.org/10.1093/aob/mcu217

Garcia, G. de O.; Nazário, A. A.; Moraes, W. B.; Gonçalves, I. Z.; Madalão, J. C. Respostas de genótipos de feijoeiro à salinidade. Engenharia na Agricultura, v.18, p.330-338, 2010.

Graciano, E. S. A.; Nogueira, R. J. M. C.; Lima, D. R. M.; Pacheco, C. M.; Santos, R. C. Crescimento e capacidade fotossintética da cultivar de amendoim BR 1 sob condições de salinidade. Revista Brasileira de Engenharia Agrícola e Ambiental, v.15, p.794-800, 2011. https://doi.org/10.1590/S1415-43662011000800005

Islã, R.; Aragués, R. Yield and plant ion concentrations in maize (Zea mays L.) subject to diurnal and nocturnal saline sprinkler irrigations. Field Crops Research, v.116, p.175-183, 2010. https:// doi.org/10.1016/j.fcr.2009.12.008

Khalid, K. A.; Silva, J. A. T. da. Yield, essential oil and pigment content of Calendula officinalis L. flower heads cultivated under salt stress conditions. Scientia Horticulturae, v.126, p.297-305, 2010. https:// doi.org/10.1016/j.scienta.2010.07.023

Khan, M. H.; Panda, S. K. Alterations in root lipid peroxidation and antioxidative responses in two rice cultivars under $\mathrm{NaCl}$-salinity stress. Acta Physiologiae Plantarum, v.30, p.81-89, 2008. https:// doi.org/10.1007/s11738-007-0093-7

Langer, K.; Levchenko, V.; Fromm, J.; Geiger, D.; Steinmeyer, R.; Lautner, S.; Ache, P.; Hedrich, R. The poplar $\mathrm{K}^{+}$channel KPT1 is associated with $\mathrm{K}^{+}$uptake during stomatal opening and bud development. The Plant Journal, v.37, p.828-838, 2004. https:// doi.org/10.1111/j.0960-7412.2003.02008.x

Lima, G. S. de; Nobre, R. G.; Gheyi, H. R.; Soares, L. A. dos A.; Silva, A. O. da. Crescimento e componentes de produção da mamoneira sob estresse salino e adubação nitrogenada. Engenharia Agrícola, v.34, p.854-866, 2014. https://doi.org/10.1590/S010069162014000500005

Marschner, H. Mineral nutrition of higher plants. 3.ed. London: Elsevier, 2012. 643p.

Melo, A. S. de; Silva Junior, C. D.; Fernandes, P. D.; Brito, M. E. B.; Sobral, L. F.; Suassuna, J. F.; Viégas, P. R. A.; Ferraz, R. L. de S. Chlorophyll and macronutrients content in leaf tissue of Musa sp 'Prata-Anã' under fertigation. African Journal of Agricultural Research, v.9, p.1714-1720, 2014. https://doi.org/10.5897/ AJAR2014.8683

Mesquita, F. de O.; Cavalcante, L. F.; Batista, R. O.; Medeiros, R. F.; Rodrigues, R. M.; Santos, W. de O. Avaliação da taxa de crescimento absoluto de mamão Havaí sob o efeito salino e de biofertilizante: Parte I. Magistra, v.26, p.443-455, 2014.

Mesquita, F. de O.; Rebequi, A. M.; Cavalcante, L. F.; Souto, A. G. de L. Crescimento absoluto e relativo de mudas de maracujazeiro sob biofertilizante e águas salinas. Revista de Ciências Agrárias, v.35, p.222-239, 2012. 
Munns, R.; Tester, M. Mechanism of salinity tolerance. Annual Review of Plant Biology, v.59, p.651-681, 2008. https://doi.org/10.1146/ annurev.arplant.59.032607.092911

Musser, R. S. Tratos culturais na cultura da acerola. In: São José, A. R.; Alves, R. E. (eds.). Acerola no Brasil: Produção e mercado. Vitória da Conquista: DFZ/UESB, 1995. p.47-52. Circular Técnica, 6

Nobre, R. G.; Gheyi, H. R.; Correia, K. G.; Soares, F. A. L.; Andrade, L. O. de. Crescimento e floração do girassol sob estresse salino e adubação nitrogenada. Revista Ciência Agronômica, v.41, p.358365, 2010. https://doi.org/10.1590/S1806-66902010000300006

Oliveira, A. P. de; Bandeira, N. V. da S.; Dantas, D. F. da S.; Silva, J. A. da; Dantas, T. A. G. Produtividade máxima e econômica do inhame em função de doses de potássio. Revista Caatinga, v.26, p.110-115, 2013.

Ouhaddach, M.; Elyacoubi, H.; Douaik, A.; Rochdi, A. Morphophysiological and biochemical responses to salt stress in wheat (Triticum aestivum L.) at the heading stage. Journal of Materials and Environmental Sciences, v.9, p.1899-1907, 2018.

Richards, L. A. Diagnosis and improvement of saline and alkali soils. Washington: U. S. Department of Agriculture, 1954. 160p. Agriculture Handbook, 60
Sá, F. V. da S.; Gheyi, H. R.; Lima, G. S. de; Paiva, E. P. de; Fernandes, P. D.; Moreira, R. C. L.; Silva, L. de A.; Ferreira Neto, M. Water relations and gas exchanges of West Indian cherry under salt stress and nitrogen and phosphorus doses. Journal of Agricultural Science, v.9, p.168-177, 2017.

Sá, F. V. da S.; Gheyi, H. R.; Lima, G. S. de; Paiva, E. P. de; Moreira, R. C. L.; Silva, L. de A. Water salinity, nitrogen and phosphorus on photochemical efficiency and growth of West Indian cherry. Revista Brasileira de Engenharia Agrícola e Ambiental, v.22, p.158-163, 2018. https://doi.org/10.1590/1807-1929/agriambi. v22n3p158-163

Sales, M. A. L.; Moreira, F. J. C.; Eloi, W. M.; Ribeiro, A. A.; Sales, F. A. L.; Monteiro, R. N. F. Germinação e crescimento inicial do coentro em substrato irrigado com água salina. Revista Brasileira de Engenharia de Biossistemas, v.9, p.221-227, 2015. https://doi. org/10.18011/bioeng2015v9n3p221-227

Souza, L. de P.; Sena, G. S. A. de; Nobre, R. G.; Barbosa, J. L.; Souza, C. M. A. de; Elias, J. J. Formação de porta-enxerto de goiabeira submetidas a diferentes salinidades da água e adubação nitrogenada. Revista Brasileira de Agricultura Irrigada v.11, p.1578-1587, 2017. https://doi.org/10.7127/rbai.v11n400618 